\title{
Perception of presence, impact and control of the invasive species Sus scrofa in the local community living near the Itatiaia National Park, Brazil
}

\author{
Carina Zanco Pereira ${ }^{1}$, Clarissa Rosa², Antônio Carlos da Silva Zanzini ${ }^{1}$
}

\begin{abstract}
Wild pigs are considered one of the 100 worse invasive species in the world and they are expanding their range throughout Brazilian territory, leading to many social and environmental impacts. The aim of our study is to estimate the perception of rural communities in the vicinity of the Itatiaia National Park (INP), Brazil regarding the presence of wild pigs, including the perceived impacts and the acceptance of management policies of the species. We conducted this study in nine rural communities around the INP, where we interviewed 210 inhabitants using structured questionnaires with ten closed dichotomous questions. The majority of respondents know about the existence of the wild pigs in the region and perceive their presence to be undesirable and a threat to the environment and crops, mainly corn, vegetable gardens and sugarcane. Most of respondents are favorable to control measures and eradication of the species, showing a common goal between local community and INP's managers and an opportunity of effective management of the species in the region. We reinforce the importance of wild pig management programs in the region that involves different social actors, including the INP managers, farmers and legal hunters properly certified by Brazilian legislation.
\end{abstract}

Keywords: Biological Invasions; Feral Hogs, Game Species; Human-Wildlife Conflict.

1 Setor de Ecologia e Manejo da Vida Silvestre, Departamento de Ciências Florestais, Universidade Federal de Lavras, Campus S/N, Centro, Lavras, Brazil, CEP 37200-000.

2* Laboratório de Ecologia e Conservação de Mamíferos, Setor de Ecologia, Departamento de Biologia, Universidade Federal de Lavras, Campus S/N, Centro, Lavras, Brazil, CEP 37200-000.

* Corresponding author. $\mathrm{E}$ E-mail address: rosacla.eco@gmail.com

\section{INTRODUCTION}

Biological invasions are one of the major causes leading to biodiversity loss worldwide, changing ecological processes and food webs (Long 2003), as well as causing negative impacts on the economy, public health and socio-cultural values (Bellard et al. 2016; Clout and Rusell 2007; Long 2003; Mooney et al. 2005). Wild boars (Sus scrofa), ungulates native to Eurasia and the northeast of Africa, were one of the first animal species domesticated by humans (i.e. domestic pigs) and intentionally 
introduced worldwide as a source of protein and for their great capacity to adapt to new environments (Courchamp et al. 2003; Long 2003). The invasive form of wild boars and feral pigs are known as wild pigs (Keiter et al. 2016), currently one of the most widely distributed invasive mammal species and one of the 100 worse invasive species in the world (Lewis et al. 2017; Long 2003; Lowe et al. 2000).

The wild pig is an omnivorous species of large size (may be over $300 \mathrm{~kg}$ ), rapid growth and high reproductive rates. These characteristic are generating innumerous social, economic and environmental conflicts in ecosystems invaded by wild pigs (BarriosGarcia and Ballari 2012; Cuevas et al. 2012; Dovrat et al. 2012; Li et al. 2013; Thurfjell et al. 2009).

In Brazil, the species was first registered in the southwest frontier between Rio Grande do Sul state and Uruguay, probably due to a drought that occurred in 1989, when the levels of the Jaguarão river were low enough that the wild pigs were able to cross the river from Uruguay to Brazil (Salvador 2012). After successive introductions of new genetic lineages of wild boars from Germany, France and Uruguay for captive breeding in Brazil, and intentional and unintentional releases, the wild pig distribution range in Brazil has expanded (Salvador 2012). Currently, conservative estimates indicate that wild pigs occur in approximately 550 municipalities within Brazilian states (MMA/MAPA 2017) and their populations are expanding all over the country due to the introduction of animals for hunting, meat consumption and absence of natural predators (Torres et al. 2012).

The social and environmental impacts caused by wild pigs are daily more common in Brazil (Pedrosa et al. 2015; Rosa et al. 2016), and many people are controlling the species, as this has been authorized by Brazilian law since 2013 (Rosa et al. 2018). The Brazilian legislation allows the use of traps followed by slaughter and hunting techniques (e.g. stand, hunt with or without dogs), and places the community as being co-responsible for the control of the wild pigs in all national territory. Undertaking efforts toward control methods that seek the artificial balance of the species, together with hunting pressure, might be a viable alternative to the uncontrolled expansion and consequent damage caused by the wild pigs in Brazil (Rosa et al. 2018).

Controlling the wild pig population is the first regulated action of a hunting activity nationwide over the past 50 years (Rosa et al. 2016). Nevertheless, the actions behind this control method are controversial, and usually followed by polemics involving many social segments, especially the local community of the environments invaded by alien species (Shackleton et al. 2019). Due to this fact, public opinion might be taken into consideration as a necessary and integrated component when facing the impacts caused by alien invasive species. Furthermore, the programs to control the species problems might have more possibility of success when accompanied by the acceptance of the population and voluntary support from all the people involved (Hulme et al. 2009).

The perception from the inhabitants of the rural communities in the locations surrounding protected areas (PAs) became more important in face of the fact that the community might have a direct interest in using the wild pigs, which may favor the invasion or the maintenance of the invasive population, or the community might have a direct interest in controlling the animal, since they harm and impact the environment and the society leading to economic losses 
(Barrios-Garcia and Ballari 2012; Li et al. 2013; Shackleton et al. 2019; Thurfjell et al. 2009). Our study has three main objectives: (1) to evaluate the perception of the rural communities in the surrounding areas of the Itatiaia National Park, Brazil, regarding the presence of wild pigs in the region; (2) to identify the main environmental and social impacts perceived by the rural communities;

(3) to evaluate the perception of the rural communities regarding the management actions (control and eradication) of the wild pigs in the region.

\section{MATERIAL AND METHODS}

\section{Study area}

We conducted our study in the surrounding areas of the Itatiaia National Park (INP; under the coordinates 44'15' and 44 ${ }^{\circ} 50^{\prime} \mathrm{W}$ and $22^{\circ} 19^{\prime}$ and $\left.22^{\circ} 45^{\prime} \mathrm{S}\right)$. The INP is located in the Serra Mantiqueira, one of the biggest and most important mountain ranges of the Brazilian southeast. It is an area considered irreplaceable for world biodiversity conservation (Le Saout et al. 2013), integrating the Atlantic Forest domain hotspot (Myers et al. 2000).

The INP is the first Protected Area. Created in Brazil in 1937 by Decree number 1,713 initially with an area of 11,934 hectares, it was expanded to 28,084 hectares in 1982 through Decree number 87,586 . The INP altitudes range from $600 \mathrm{~m}$ to $2791 \mathrm{~m}$ above sea level, with the INP situated between the states of Minas Gerais and Rio de Janeiro, comprising the municipalities of Bocaina de Minas (11.34\% of the INP), Itamonte (22.28\% of the INP), Itatiaia $(35.36 \%$ of the INP) and Resende (4.15\% of the INP) (Iwamoto and Rodrigues 2011). The highest altitudes of INP and surroundings (from $1500 \mathrm{~m}$ to $2791 \mathrm{~m}$ of altitude), where the invasion of the wild pigs is concentrated (Abreu 2016), are characterized as with a Cwb climate, altitudinal subtropical with dry winters and warm summers (Köppen 1936). The main phytophysiognomy is the Montane Semideciduous Forest, characterized by the presence of araucaria trees (Araucaria angustifolia (Bertol.) Kuntze) and, above $2000 \mathrm{~m}$, high altitude grasslands (OliveiraFilho and Fontes 2000; Ururahy et al. 1983).

Wild pigs invaded the region in 2006 crossing the municipality of Itanhandu, next to the INP, when six individuals including females and juveniles, with the fenotipe similar to the European wild boar, were released from a farm and established a feral population in the region, according to local inhabitants. Five years later, many rural producers and PAs managers from the region began to have problems with the wild pigs, mainly due to the attacks on crops and gardens, degradation of streams, springs and predation of araucaria seeds (Rosa 2016). Since 2014 the managers of the INP perform as needed action to control the wild pigs inside park territory (Rosa et al. 2016).

Our research population was made up of local rural inhabitants of the nine communities located in the surrounding areas of the INP (Engenho da Serra, Colina, Vargem Grande, Serra Negra, Fragária, Capivara, Campo Redondo, Dois Irmãos and Monte Belo), all located in Itamonte municipality (Figure 1).

\section{Method and sample size}

Our study is descriptive, based on opinion research and frequency of occurrence of an event through obtaining individual points of view and preferences regarding a specific topic, with the aim to subsidize the decision making process. We sampled the perception 

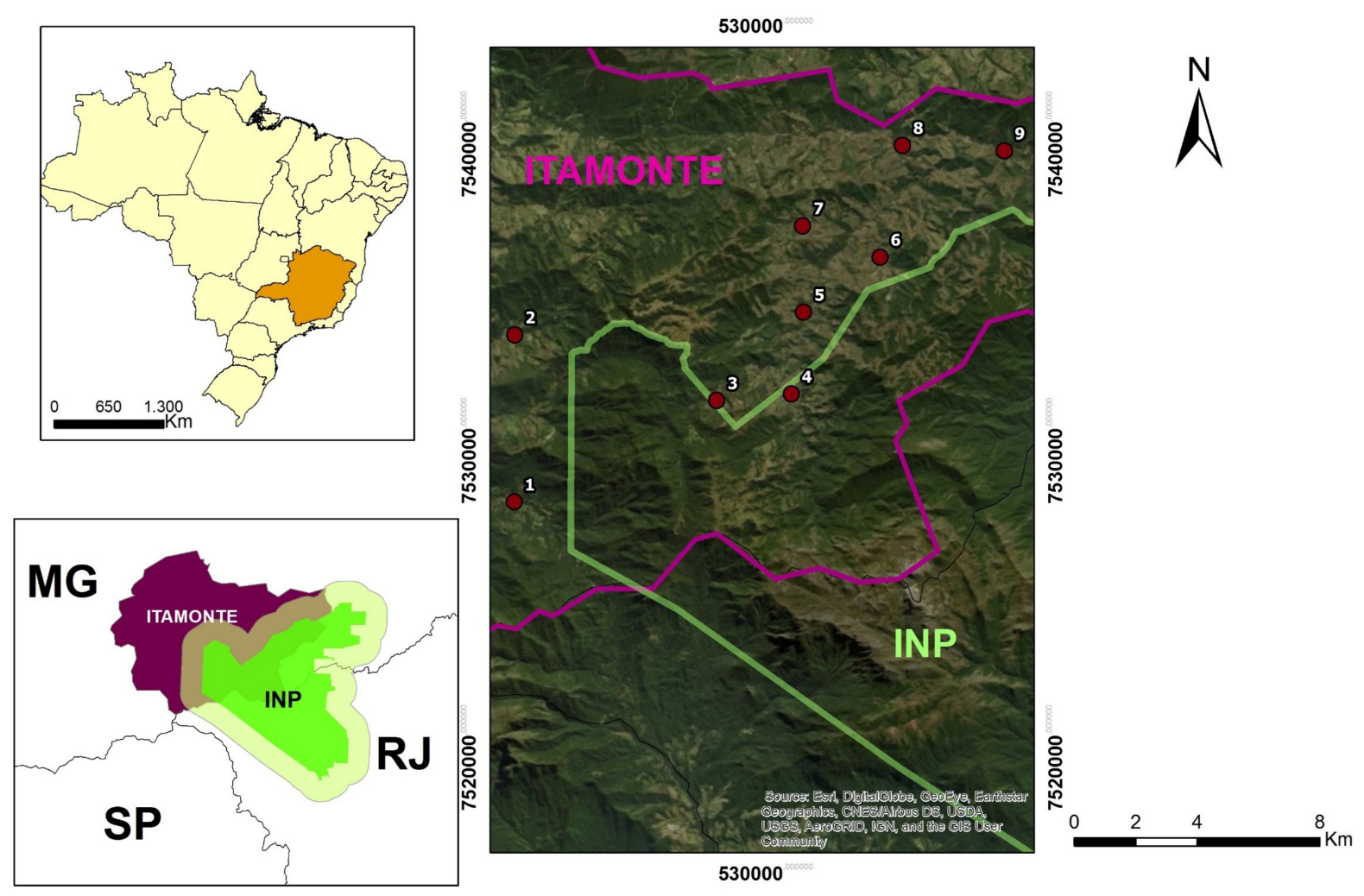

Figure 1. Geographical context of the Itatiaia National Park (INP) in Brazil. The polygon in green defines the limits of the INP and the red points represent the location of the nine rural communities sampled: (1) Engenho da Serra, (2) Colina, (3) Vargem Grande, (4) Serra Negra, (5) Fragária, (6) Capivara, (7) Campo Redondo, (8) Monte Belo and (9) Dois Irmãos.

of the local inhabitants regarding the presence of the wild pigs applying structured questionnaires with closed dichotomous questions The questionnaire involves the organization of a series of questions applied systematically to a determined number of people granting uniformity and standardization of the collected information (Chaer et al. 2011; Oliveira et al. 2010).

To define the size of the sample (number of respondents in each community), and for the sampling error, we used a probabilistic sample for finite populations based on the population proportion, which allowed us statistical inferences from the answers of respondents. From 460 households at the nine rural communities available for this study (IBGE 2019), we selected 210 households (Table 1) according to the equations:

$$
\begin{aligned}
& e=z_{\alpha / 2} \cdot \sqrt{\frac{\hat{p} \cdot \hat{q}}{n}} \cdot \sqrt{\frac{N-n}{n-1}} \\
& n=\frac{N \cdot \hat{p} \cdot \hat{q} \cdot z^{2}}{\hat{p} \cdot \hat{q} \cdot z_{\alpha / 2}^{2}+(N-1) \cdot e^{2}}
\end{aligned}
$$

\section{Where:}

$\mathrm{n}=$ size of the sample for finite populations.

$\mathrm{N}=$ total number of households in the study area.

p e $q=$ split applied $=$ probability of the searched population being homogenous or heterogeneous (in this study, we applied a split of $=50 / 50$, meaning that the probability 
of obtaining a "yes" or "no" response for a determined question of the structured questionnaire is the same).

$z=$ distribution of the normality curve standardized for the values of $z$.

$\alpha=$ level of significance for the estimated size of the sample (in this case, we established a significance level of $\alpha=0,05$ ).

$\mathrm{e}=$ error margin applied in our research (in this case, it will be $5 \%$ or five percentage points, for more or less, related to the sample size adopted).

\section{Sampling and data analyzes}

We applied one questionnaire in each of the 210 households selected. In each home we interviewed only one inhabitant with the characteristics of being an adult and performing rural activities. Our questionnaires first approached the respondent profile as to age, educational level, profession, local and time of residence and work in the region and knowledge regarding the native species. We then asked 10 questions approaching themes like the perception about the presence and possible environmental and social damage (harm to the native vegetation, damage to crops, domestic and wild animal attacks) caused by the wild pigs and the perception of the community about the implementation of control and eradication managements on the wild pigs in the region (Table 2 ). To evaluate the statistical significance $(\alpha=0.05)$ of the answers we utilized the chi-square $(x 2)$ test (Krebs 1989).

\section{RESULTS}

The existence of the wild pigs in the region is known by $96 \%(N=202)$ of the inhabitants of the areas surrounding the INP.
The majority of the respondents $(90 \%, \mathrm{~N}=$ 188) perceive the presence of the wild pig as a threat to the environment and consider the coexistence between wild pigs and the rural producers as undesirable $(91 \%, N=192)$ (Figure 2, Table 3).

Among the impacts caused by the wild pigs in the local community, the attack to crops was reported by $94 \%(\mathrm{~N}=198)$ of respondents. The local inhabitants reported attacks to corn, sugarcane, carrot and strawberry crops and gardens with pumpkin, resulting in economic losses of small properties that vary from USD $\$ 500,00$ to U\$3.000,00. The respondents also report the destruction of natural springs water fountains and water pipes. The damage to the native vegetation was reported by $43 \%(\mathrm{~N}=90)$ of the respondents and the attack to domestic and wild animals was reported by $45 \%$ ( $\mathrm{N}=$ $94)$ and $42 \%(N=89)$ of the respondents, respectively (Figure 2, Table 3).

The majority of respondents report the existence of wild pig hunting in the INP surroundings $(66 \%, N=138)$ and $90 \%(N=$ 190) are favorable to management measures of the wild pigs, with $70 \%$ ( $\mathrm{N}=$ 147) hoping for the eradication of the species in the region (Figure 2, Table 3).

\section{DISCUSSION}

Our results show that wild pigs are widespread in the surroundings of INP and the species is undesirable to the land owners due to the social and environmental impacts that they cause to small farms. Wild pig attacks on crops, especially corn and sugarcane, have been reported in many Brazilian regions (MMA/MAPA 2017; Pedrosa et al. 2015). This is extremely worrisome because Brazil is a large producer of these crops, on small, medium and large farms (IBGE 2019), providing a 
Table 1: Number of total households sampled (number of questionnaires applied) in each rural community of the municipality of Itamonte, Minas Gerais, Brazil.

\begin{tabular}{lll}
\hline Community & Total of Households & Households Sampled \\
\hline Engenho da Serra & 97 & 44 \\
Colina & 116 & 53 \\
Vargem Grande & 30 & 14 \\
Serra Negra & 30 & 14 \\
Fragária & 31 & 14 \\
Capivara & 30 & 14 \\
Campo Redondo & 86 & 39 \\
Dois Irmãos & 20 & 09 \\
Monte Belo & 20 & 09 \\
Total & $\mathbf{4 6 0}$ & $\mathbf{2 1 0}$ \\
\hline
\end{tabular}

Table 2: Questions and answers presented on the questionnaires applied to the local communities of Itamonte, Minas Gerais, Brazil, regarding the invasions by wild pigs.

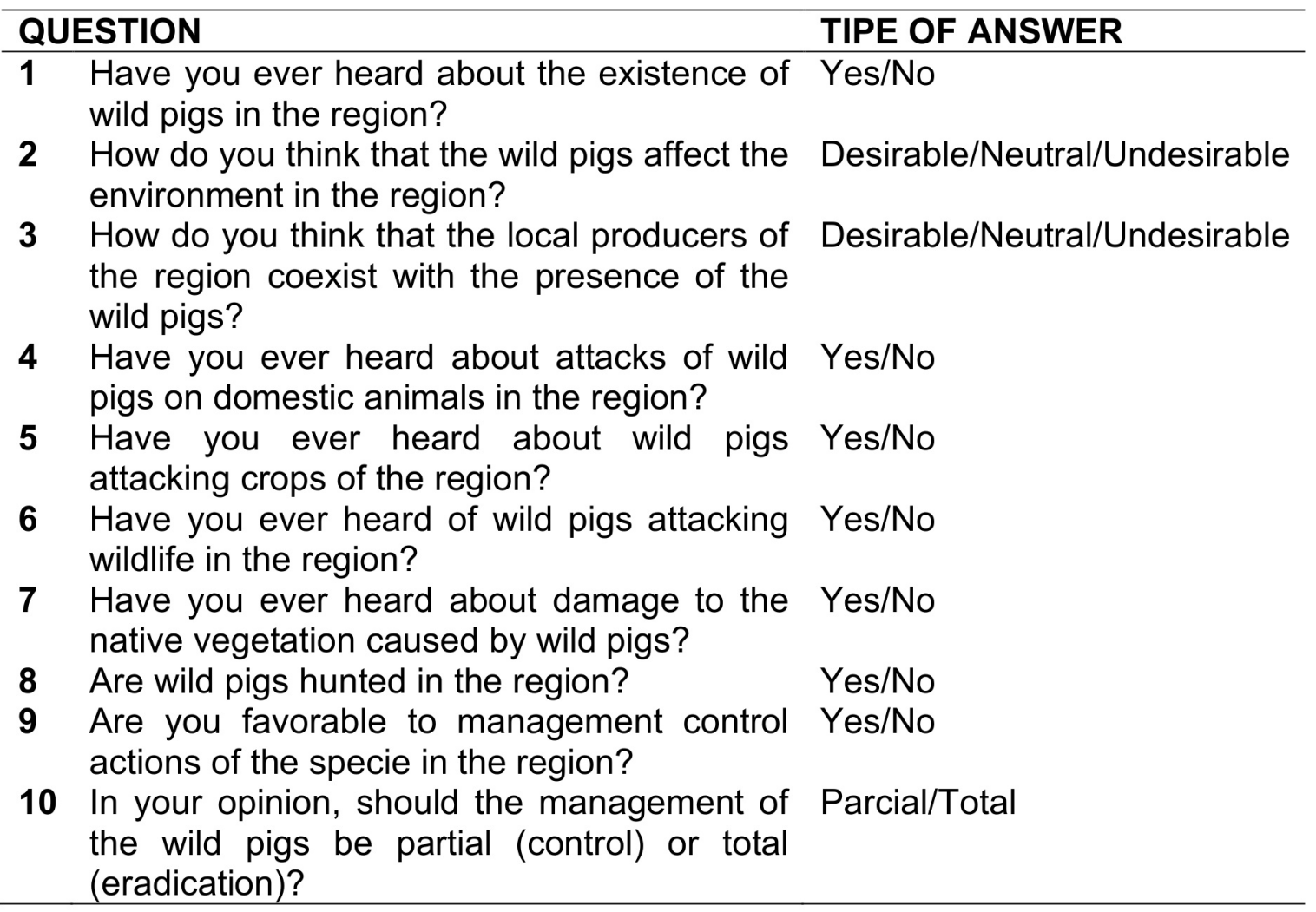

wide supply of food to wild pigs and, the increase of human populations in the consequently, accelerating their reproduction rates and the biological invasion process (Frauendorf et al. 2016; Geisser and Reyer, 2005). On small farms, the impacts of the wild pigs may lead to rural exodus (Rosa et al. 2016), generating social conflicts due to cities. Furthermore, the destruction of natural springs is common on small farms, the same occurs inside the INP (Rosa 2016), a protected area that has the main goal of protecting water resources.

The ISSG recommends that all the 
Table 3: Chi-square values for the answers of respondents. * statistically significant values.

\begin{tabular}{llll}
\hline Question & Tested variable & $\mathbf{X}^{\mathbf{2}}$ Value & P Value \\
\hline $\mathbf{1}$ & Yes X No & 191.8 & $0.0001^{*}$ \\
$\mathbf{2}$ & Neutral X Undesirable & 266.0 & $0.0001^{*}$ \\
$\mathbf{3}$ & Neutral X Undesirable & 367.0 & $0.0001^{*}$ \\
$\mathbf{4}$ & Yes X No & 5.472 & 0.218 \\
$\mathbf{5}$ & Yes X No & 51.80 & $0.0001^{*}$ \\
$\mathbf{6}$ & Yes X No & 6.022 & 0.390 \\
$\mathbf{7}$ & Yes X No & 7.071 & 0.419 \\
$\mathbf{8}$ & Yes X No & 22.56 & $0.0001^{*}$ \\
$\mathbf{9}$ & Yes X No & 258.5 & $0.0001^{*}$ \\
$\mathbf{1 0}$ & Parcial X Total & 36.3 & $0.0001^{*}$ \\
\hline
\end{tabular}

naturalized wild pig populations need to be considered as alien pests to be controlled, reduced in number or eradicated the best way possible, even before detecting any environmental, economic or social impact (Oliver et al. 1993). A first step to advance the management of the wild pigs is recognizing the problem and the view that the control of invasive populations will only be reached when there is an integration of different methods and social actors (Hulme et al. 2009, Massei et al. 2011). For this, wide social participation is important to define a common objective (control or eradication) and to expand the public acceptance of the control methods, as it is key to the success of any management program (Hulme et al. 2009, Massei et al. 2011).

Since hunting is a traditional activity for rural populations in Brazil (Alves et al. 2016; Bezerra et al. 2012, Fernandes-Ferreira and Alves 2014), the inhabitants of the Itamonte municipality started to slaughter the animals as soon as they had economic losses (Rosa et al. 2016; 2018). In the surrounding areas of the INP, the farmers are controlling the wild pigs with the resources they have, with unregistered weapons of inadequate caliber, building ineffective traps or using techniques not allowed by Brazilian law (Rosa et al. 2016; 2018). The community around the INP has a direct interest in controlling the wild pigs, as they are also harmed by the species through the destruction of crops and gardens, showing common issues between community and environmental agencies, generating a large opportunity to manage the species in the region (Hulme et al. 2009; Massei et al. 2011).

However, when facing a situation that requires urgent solutions, we need to assign a higher relevance to the actions of those who are aligned with the most recent scientific studies on the theme. This will assure a basis fairer to the discussions, discussions which many times have a personal character, mainly sentimental and scientifically weakly based. This is especially true in Brazil, a country not accustomed to having regulated hunting or wildlife control activities. Also, Brazil has many challenges to overcome, in face of the historical negligence of the country's government regarding the environment, and controlling the wild pigs is not a priority for the Brazilian PAs. In the specific case of the INP, the oldest PA in the country, managers deal with many land ownership, poaching and palm tree logging conflicts, while trying to control 


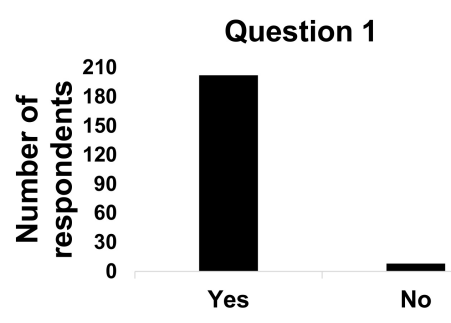

Question 3

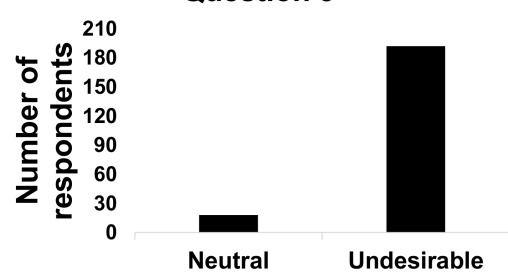

Question 5
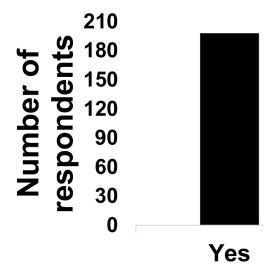

Question 7
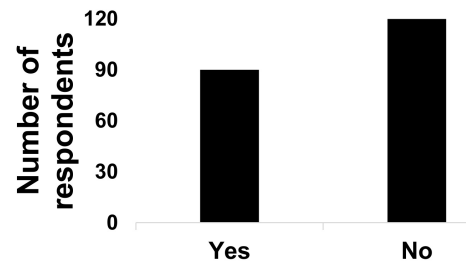

Question 9

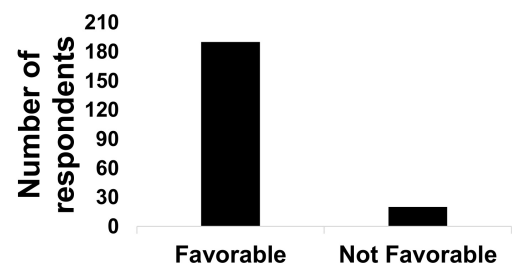

Question 2

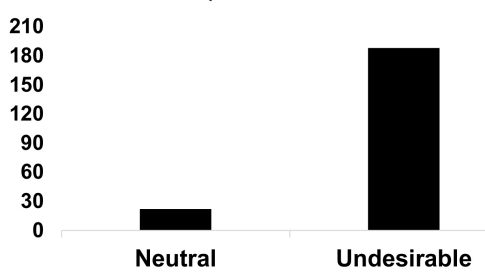

Question 4
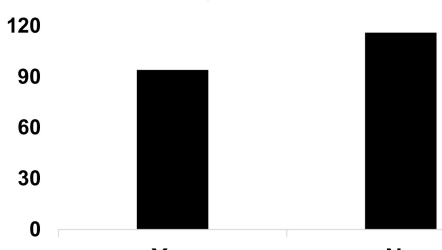

No

Question 6

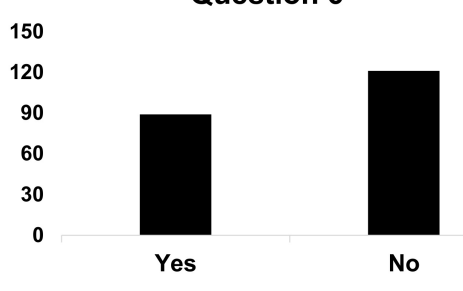

Question 8

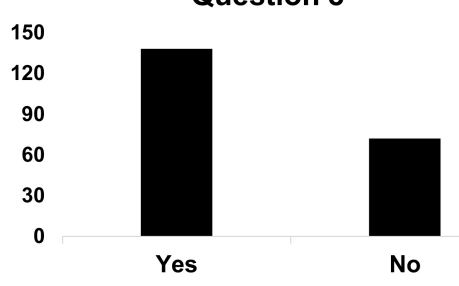

Question 10

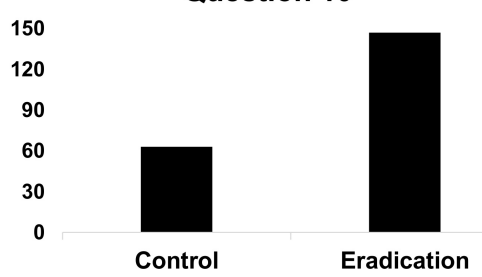

Figure 2. Responses to the questions answered by 210 respondents in Itamonte, MG, Brazil. Question 1: Have you ever heard about the existence of wild pigs in the region? Question 2: How do you think that the wild pigs affect the environment in the region? Question 3: How do you think that the local producers of the region coexist with the presence of the wild pigs? Question 4: Have you ever heard about attacks of wild pigs on domestic animals in the region? Question 5: Have you ever heard about wild pigs attacking the crops of the region? Question 6: Have you ever heard of wild pigs attacking wildlife in the region? Question 7: Have you ever heard about damage to native vegetation caused by the wild pigs? Question 8: Are the wild pigs hunted in the region? Question 9: Are you favorable to management actions of the species in the region? Question 10: In your opinion, should the management of the wild pigs be partial (control) or total (eradication)? 
the wild pig populations using hunting and traps followed by slaughter. The lack of physical structure and the low number of employees at the INP makes the use of traps inefficient and unviable, as there is no structure to support these actions in the Park (Rosa, unpublished data). This becomes a waste of time and financial resources, and even threatens the animal welfare in the sense that is impossible to daily revise the traps (Massei et al. 2011). Sloped ground and the absence of roads in most of the areas of the INP also do not allow the use of traps in the main areas where the wild pigs are invading. Therefore, hunting becomes a viable alternative to control the wild pigs at the INP.

For these reasons, an institutional program that brings the unregulated hunters to legality is fundamental to the participation of the local community to control the wild pigs in an integrated management program with governmental agencies and PA managers. The hunters might be instructed and trained to reduce risks, to improve the effective control of the activity and to keep malicious people from using regulated hunting activities for poaching in a place with high biodiversity. We also recommend the creation of guidelines for the community regarding the usage of traps that might be incorporated in the daily activities of the farmers in the surrounding areas of the INP. Also, an integrated control program with the managers from PAs and the community can be very effective to avoid further invasions (Barrios-Garcia and Ballari 2012; Li et al. 2013; Thurfjell et al. 2009).

Partnerships between public agents and the rural community, which has the folk knowledge of the territory, is fundamental to the establishment of necessary strategies to contain the expansion of the wild pigs and reduce the damage by this species in Brazil.
For this, it is necessary to work together and to capacitate the local community in a way that the control of the wild pig is reached respecting the legislation and the safety recommendations for the activities, regardless of the method utilized. It is necessary to undertake the difficult work of raising community and INP awareness regarding the policies for the environmental issues, highlighting the sanitary, ecologic and economic risks caused by the presence of the wild pigs to the domestic animals and the human population.

\section{CONCLUSIONS}

Our work concluded that, seven years after introducing the wild pigs in the region, the species is seen by the land owners as well known and unpopular due to the social and environmental impacts that they cause to small farms around the INP. This negative impacts lead to a perception by the community regarding the importance to control the wild pig populations.

The invasions by wild pigs disrupts the 'untouched nature' paradigm, something very common in the environmental policies in Brazil. Currently, nowadays no PA in the country can take any effective control methods regarding the wild pigs without including segments society, be them hunters or farmers. We believe that a national program involving society will gather the community around the PAs, creating a relationship of confidence with the managers, while resulting in benefits to the reduction of other conflicts, like poaching and logging. 


\section{REFERENCES}

Abreu T (2016) Análise da ocupação do javali (Sus scrofa) no Parque Nacional do Itatiaia e entorno (Serra da Mantiqueira). MSc. Dissertation, Universidade Federal de Lavras, Lavras, Brazil.

Alves RRN, Feijó A, Barboza RRD, Souto WMS, Fernandes-Ferreira $H$, Cordeiro-Estrela $P$, Langguth A (2016) Game mammals of the Caatinga biome. Ethnobiology and Conservation 5: $1-51$.

Barrios-Garcia M, Ballari S (2012) Impact of wild pig (Sus scrofa) in its introduced and native range: a review. Biological Invasions 14:2283-2300

Bellard C, Cassey P, Blackburn TM (2016) Alien species as a driver of recent extinctions. Biology Letters 12:20150623

Bezerra DMM; Araujo HFP, Alves RRN (2012) Captura de aves silvestres no semiárido brasileiro: técnicas cinegéticas e implicações para conservação. Tropical Conservation Science 5: 50-66.

Chaer G; Diniz RRP; Ribeiro EA (2011) A técnica do questionário na pesquisa educacional. Evidência 7(7):251-266

Clout MN, Russell JC (2008) The invasion ecology of mammals: a global perspective. Wildlife Research 35:180-184

Courchamp F, Chapuis J, Pascal M (2003) Mammal invaders on islands: impact, control and control impact. Biological Reviews 78:347-383

Cuevas MF, Mastrantonio L, Ojeda RA, Jaksic FM (2012) Effects of wild pig disturbance on vegetation and soil properties in the Monte Desert. Argentina. Mammalian Biology 77(1): 299-306

Dovrat G, Perevolotsky A, Ne'eman G (2012) Wild pigs as seed dispersal agents of alien plants from agricultural lands to conservation areas. Journal of Arid Environments 78(1): 49-54

Fernandes-Ferreira, H, Alves RRN (2017) The researches on the hunting in Brazil: a brief overview. Ethnobiology and Conservation 6:1-6.
Frauendorf M, Gethöffer F, Siebert U, Keuling O (2016) The influence of environmental and physiological factors on the litter size of wild pig (Sus scrofa) in an agriculture dominated area in Germany. Science of the Total Environment 541:877-882

Geisser H, Reyer H (2005) Efficacy of hunting, feeding, and fencing to reduce crop damage by wild pigs. Journal of Wildlife Management 68: 939-946

Hulme PE, Pysez P, Nentwig W, Vila M (2009) Will threat of biological invasions unite the European Union? Science 324(5923):40-41

IBGE (2009) Instituto Brasileiro de Geografia e Estatística. [https://www.ibge.gov.br/] Accessed 20 February 2019

Iwamoto PK, Rodrigues MG (2011) Uma proposta de delimitação da zona de amortecimento do Parque Nacional do Itatiaia, Rio de Janeiro, Brasil. Revista Nordestina de Ecoturismo 4(2):5-14.

Keiter DA, Mayers JJ, Breasley JC (2016) What is in a "common" name? A call for consistent terminology for nonnative Sus scrofa. Wildlife Society Bulletin 40:384-387

Köppen W (1936) Das geographisca System der Klimate. In: Koppen W, Geiger R (eds) Klimatologie. Gebr, Borntraeger, Germany, pp. 144

Krebs CJ (1989) Ecological Methodology. Harper and Row Publishers, Nova York, USA.

Le Saout S, Hoffmann M, Shi Y, Hughes A, Bernard C, Brooks TM, Bertzky B, Butchart SHM, Stuart SN, Badman T, Rodrigues ASL (2013) Protected areas and effective biodiversity conservation. Science 342:803-805.

Lewis JS, Farnsworth ML, Burdett CL, Theobald DM, Gray M, Miller RS (2017) Biotic and abiotic factors predicting the global distribution and population density of an invasive large mammal. Scientific Report 7:44152

Li L, Shi J, Wang J, Gao Y, Wang L, Wang J, Ying $X$ (2013) Factors influencing wild pig damage in Taohongling National Nature Reserve in China: a model approach. European Journal of Wildlife Research 59:179184 
Long JL (2003) Introduced mammals of the world: their history distribution and influence. CSIRO, Collingwood, Australia.

Lowe S, Browne M, Boudjelas S, De Poorter M (2000) 100 of the world's worst invasive alien species a selection from the Global Invasive Species Database. The Invasive Species Specialist Group (ISSG), Species Survival Commission, World Conservation Union (IUCN), Gland, Switzerland.

Massei G, Roy S, Bunting R (2011) Too many hogs? A review of methods to mitigate impact by wild pig and feral hogs. Human-Wildlife Interactions 5:79-99

MMA/MAPA (2017) Plano nacional de controle e monitoramento do javali (Sus scrofa) no Brasil. Ministério do Meio Ambiente/Ministério da Agricultura, Pecuária e Abastecimento, Brasília, Brazil

Mooney HA, Mack RN, McNeely JA, Neville LE, Schei PJ, Waage JK (2005) Invasive alien species: a new synthesis. Island Press, Washington, USA.

Myers N, Mittermeier RA, Mittermeier CG, Fonseca GAB, Kent J (2000) Biodiversity hotspot for conservation priorities. Nature 403:853-858.

Oliveira FLB, Silva JM, Valença LLS, Freire JG, Costa LS (2010) The practice of science teaching in public schools of Santa Cruz, RN. Holos 26(5): 218-226

Oliveira-Filho A, Fontes M (2000) Patterns of floristic differentiation among Atlantic Forests in Southeastern Brazil and the influence of climate. Biotropica 32: 793-810

Oliver W, Brisbin I, Takahashi S (1993) The Eurasian wild pig, Sus scrofa. In: Oliver W. (ed.), Pigs, peccaries, and hippos. Status survey and conservation action plan. World Conservation Union (IUCN), Gland, Switzerland, pp. 112-121.

Pedrosa F, Salerno R, Vinicius F, Padilha B, Galetti M (2015) Current distribution of invasive feral pigs in Brazil: economic impacts and ecological uncertainty. Brazilian Journal of Nature Conservancy 13:84-87.
Rosa CA (2016) Mamíferos Exóticos Invasores no Brasil: situação atual, riscos potenciais e impactos da invasão de porcos selvagens em Florestas Tropicais. PdH Thesis, Universidade Federal de Lavras, Lavras, Brazil.

Rosa CA, Wallau MO, Salerno R, Pedrosa F, de Souza AC, Puertas F, dos Reis TX, Mendina Filho LH (2016) An overview of feral hog control in Brazil after three years of control regulation. In: Timm RM, Baldwin RA (eds) Proceedings of the 27th Vertebrate Pest Conference. University of California, Davis, USA, pp. 178-184.

Rosa CA, Wallau MO, Pedrosa F (2018) Hunting as the main technique used to control wild pigs in Brazil. Wildlife Society Bulletin 42(1):111118.

Salvador CH (2012) Ecologia e manejo de javali (Sus scrofa L.) na América do Sul. PhD Thesis, Universidade Federal do Rio de Janeiro, Rio de Janeiro, Brazil.

Shackleton RT, Shackleton CM, Kull CA (2019) The role of invasive alien species in shaping local livelihoods and human well-being: A review. Journal of Environmental Management 229:145-157.

Thurfjell H, Spong G, Ericsson G (2013) Effects of hunting on wild pig Sus scrofa behaviour. Wildlife Biology 19: 87-93.

Torres R, Ambrósio I, Lopes I, Cancela J, Fonseca C (2012) Avaliação dos estragos causados pelo javali (Sus scrofa) na beira litoral. Silva Lusitana 20:105-122.

Ururahy JC, Collares JER, Santos MM, Barreto RAA (1983) RADAMBRASIL, Vegetação, Levantamento dos Recursos Naturais 32, Folhas SF 23/24. Rio de Janeiro/Vitória, Brazil.

Received: 18 March 2019

Accepted: 27 May 2019

Published: 11 June 2019 